\title{
A Dynamic Scoring Simulation Analysis of How TEL Design Choices Impact Government Expansion
}

\author{
John D. Merrifield a*, Barry W. Poulson ${ }^{b}$ \\ a University of Texas at San Antonio College of Business. \\ b University of Colorado at Boulder, E-mail: barry.poulson@colorado.edu \\ *Corresponding author's email address: john.merrifield@utsa.edu
}

\section{A R T I C L E I N F O}

Received: 10-02-2016

Accepted: 01-03-2016

Available online: 07-05-2016

Keywords:

Budget stabilization;

Fiscal consolidation;

Fiscal rules;

State fiscal policy.

TEL.

JEL Classification : H72

\begin{abstract}
A B S T R A C T
A dynamic scoring simulation analysis compares the size-of-government effects of four state-government-level Tax and Expenditure Limit (TEL) and Budget Stabilization Fund (BSF) combinations. Two of the four TEL-BSF combinations have population-plusinflation as the basis for the spending growth limit. The other two TEL-BSF combinations have personal-income-growth as the basis for the spending growth cap. A sensitivity analysis, including a regression analysis of Monte-Carlo-generated 'observations', measures the significance of the model parameter choices. The personal-income-growth TELs don't constrain spending growth at all in some states. In most states, a TEL based on a significant multiple of population plus inflation restrains fiscal expansion more than either version of our personal income growth TEL. The findings provide some important policy issues: there are significant differences in the fiscal and economic impacts of likely TEL design alternatives, and there is a likely trade-off between stringency and political durability.
\end{abstract}

(C) 2016 The Authors. This is an open access article under the terms of the Creative Commons Attribution License 4.0, which allows use, distribution and reproduction in any medium, provided the original work is properly cited.

DOI: http://dx.doi.org/10.18533/jefs.v4i02.211

\subsection{Introduction}

Early economic analysis of tax and expenditure limits (TELs) assessed the fiscal restraint effects of actual state and local fiscal rules. That perspective reflected the rapid growth in state government spending. It rose from $4 \%$ of GDP in the 1950s to 10\% in the 1990s (Holcombe and Sobel 1997; Merrifield 2000). And it reflects attempts at push-back; for example, TEL referenda such as Howard Jarvis' Prop 13 in California that arose in the 1970s and continue to this day. Recent extraordinary economic and fiscal stress expanded interest in TELs to include budget stability and economic growth effects. But the "unprecedented"1 ${ }^{1}$ aggregate state spending growth between the 2001 Recession and the Great Recession (Stansel and Mitchell 2008), and continued rapid growth thereafter, convinced us to focus, first, on how some possible second generation TELs would differ in terms of their effects on government size and growth. So, the purpose of our work is to compare our TEL simulation findings to the state spending record for 1998-2014. So, we assess how enforced TELs with specific features would have impacted fiscal expansion. That's a very different issue than how the first generation TELs actually impacted state

\footnotetext{
${ }^{1} \mathrm{~A} 1 / 26 / 09$ Wall Street Journal editorial ("States of Fiscal Distress") said, "The state spending binge of the last five years has been unprecedented in American history." Thirty-seven states had FY 2005-08 general fund expenditure growth (NASBO.org data) that topped Calendar 2004-2007 personal income growth (BEA data). In those 37 states, FY 2005-08 general fund spending growth averaged five percentage points above personal income growth.
} 
fiscal outcomes. Our perspective also sets aside the procedural rules issue (Kioko and Martell, 2012); that is, how TEL effectiveness varies with rules for changing a TEL's constraints on revenue or exclusions.

After the literature review and some background information, we describe our data, the 1999-2014 dynamic scoring simulation model that is our key exploratory tool, and the preferred parameter values of the four major TEL designs we examine. After we present the results that arise with our preferred parameter values, we use a sensitivity analysis that includes regression analysis of Monte Carlo-generated 'observations' to report the sensitivity of our findings to small changes in key parameters and assumptions. Policy recommendations and a summary complete the paper.

\subsection{Background facts and literature review}

The diverse fiscal stress policy responses to the Great Recession ${ }^{2}$ included tax hikes that often ratchet up state revenue and spending over the business cycle. Some states felt obliged to raise taxes or borrow money to sustain spending financed with federal stimulus funds (Young and Sobel 2013). And there has been renewed interest in TELs, though, so far, none of the formal proposals to enact caps or strengthen existing limits have been enacted. Even without new caps on revenue or spending growth, nearly every state has some spending constraints. Only Vermont lacks a balanced budget requirement. Forty-seven states have reserve funds that can help them stabilize spending during recessions and for emergency response. A variety of other fiscal rules may constrain state fiscal policies, including TELs, line item veto and super-majority vote requirements to raise taxes or issue debt. ${ }^{3}$ Probably because state legislators can easily suspend or circumvent most of the thirty-two TELs (Waisenen 2010; Zycher 2013), early studies found small and ambiguous impacts on state budgets (Abrams and Dougan, 1986; Bails, 1990; Bails and Tieslau, 2000; Howard, 1989; Joyce and Mullins, 1991; Mullins and Joyce, 1996; Poterba and Reuben, 1999; Poterba, 1994; Poulson and Kaplan, 1994). More recent research reveals that TEL effectiveness depends upon TEL design (Bails and Tieslau, 2000; Elder, 1992; Kousser et al., 2008; Merrifield 2000; Merrifield and Monson, 2011; Merrifield and Poulson, 2014b; Mitchell, 2010; Mitchell and Tusyznski, 2011; New, 2001, 2003; Poulson, 2004; Shadbegian, 1996; Stansel, 1994; Stansel and Mitchell 2008).

The most important design issues are spending category exemptions, the basis for the cap on the growth of state spending/revenues, and whether "re-basing (see below)" (Kioko, 2011) occurs if actual spending or revenue falls short of the cap amount. Seventeen states have TEL caps based on some measure of personal income, typically annual, or average annual, rate of growth in personal income. Six states link their TEL to spending as a share of personal income. When TEL caps linked to personal income are binding, the instability in personal income growth results in volatility in state spending over the business cycle (Crain, 2003; Holcombe and Sobel 1997; Kioko, 2011; Krol, 2007; Mitchell, 2010; Mullins and Wallin, 2004; Schunk and Woodward, 2005; Shadbegian, 1996; Wagner and Elder, 2005; Waisenen 2010). And the tax base of some states keeps personal income growthbased TELs from being binding very often.

The effectiveness of personal income-based TELs as state budget limits also depends upon the economic conditions and business cycle phase when they take effect (Mitchell, 2010). For example, they seem to be more binding in low income states. Florida introduced a TEL linked to personal income in the recession phase of the business cycle that was never binding. The spending cap rose more rapidly than the actual growth in state revenue. Inflation plus the rate of population growth is the basis of the most restrictive TELs. Arkansas, California, Colorado, Nevada, Ohio, Utah, and Washington have that type of TEL.

The impact of TELs on the size or growth in state budgets can depend upon what is referred to as 'rebasing' in the literature. When actual spending falls below the spending allowed by the TEL ceiling, re-basing creates a lower base against which the cap is applied in future years, a so-called 'ratchet down' effect. Ten states do such an annual 'rebasing' of their TEL (Kioko, 2011) cap. Five of those states use actual revenue or expenditures as the base for future budget caps: Connecticut, Montana, New Jersey, Texas, and Washington. The other five states set the limit as a percent of annually estimated revenues: Delaware, Iowa, Missouri, Oklahoma, and Rhode Island.

The 'ratchet down' effect of re-based TEL caps is controversial. For example, Colorado's original TEL (the Taxpayer Bill of Rights Amendment enacted in 1992) applied a stringent limit, inflation plus population growth, to actual revenue or allowable revenue, whichever was lower, and did not provide for a reserve fund to sustain spending growth above revenue growth when revenue grew more slowly than population plus inflation. So, after years of

\footnotetext{
2 Demands for state government services tend to be countercyclical, whereas the revenue stream is pro cyclical (Holcombe and Sobel 1997).

3Similar issues arise in the discussions of state fiscal rules and fiscal consolidation and fiscal adjustment at the national level (Agenor and Yilmaz 2011, Fatas and Mihov 2006, Bird and Mandilaras 2013). Critics argue that state rules such as the balanced budget requirement are pro-cyclical and depress productive public investment and spending.
} 
budget expansion at population plus inflation, plus surplus revenue rebates to taxpayers, Colorado experienced a spending 'ratchet down' effect when the 2001 Recession kept revenue growth well below population plus inflation. The spending limit fell more than it would have had the state kept some pre-recession surplus funds in a budget stabilization fund (BSF), or been allowed to catch up to the population plus inflation trend line once revenue growth recovered. So, the recession-driven shortfall below the cap amount set a lower limit on spending growth in the subsequent years of economic recovery. Dissatisfaction with that yielded narrow voter approval of Referendum C in 2005 which eliminated the annual rebasing feature of Colorado's TEL. The new TEL cap now bases allowable growth on the previous year's allowable spending, not actual expenditures. This is a good example of how TELs can change over time if voters become convinced that the TEL cap is overly stringent, and it signals a likely trade-off, at some level(s) of stringency between stringency and initial political feasibility and between stringency and political sustainability. A perception of excess stringency weakened Colorado's TABOR, while, arguably gradually leading to the now virtual irrelevance of California's TEL (the GANN spending limit that constrained California's spending growth in the 1980s).

The spending reduction achieved by a TEL also depends on the disposition of surplus revenue. Four states simply keep the surplus in the general fund (Arkansas, Hawaii, South Carolina, and Texas), leaving long-term spending unaffected. California, Colorado, Massachusetts, and Oregon rebate surplus revenue to taxpayers. Thirteen states allocate a portion of the surplus revenue to a budget stabilization fund (BSF). Surplus revenue may also be earmarked for emergency funds, capital funds, maintenance and repair, education, or debt relief (Merrifield and Monson, 2011; Primo 2006; Waisenen 2010; Zycher 2013).

\subsection{Dynamic simulation analysis of TELs}

Our dynamic scoring simulation model assesses two variations each of the two basic TEL basis options: 1a.) Population + Inflation; and 1b.) Because some legislators claim that pressures, such as pension liabilities and federal Medicaid mandates, can make a population growth plus inflation TEL too stringent, we explore (population growth plus inflation) $\mathrm{x} 1.2$ as a TEL basis; $2 \mathrm{a}$.) The most recent annual growth in personal income; and $2 \mathrm{~b}$.) A seemingly less volatile personal income growth TEL basis is the average rate of increase for the previous ten years.

To focus on differences in TEL/BSF design, the model assumes effective enforcement of the model's caps. Except in some of the sensitivity analyses of our four TEL versions, each year's full BSF balance is available to bridge gaps between revenue and the TEL cap. So, in each period, General Fund spending is at the cap amount when revenue, or revenue plus BSF account balance, is equal to or greater than the cap amount. The BSF deposit-withdrawal rules allocate $100 \%$ of positive differences between revenue and the spending cap amount to the BSF, up to its account balance cap of ten percent of expected General Fund spending.

Our simulation model includes dynamic scoring to capture economic growth effects of the TEL impact on the size of government. Based on longstanding benefit-cost analysis practice the model uses a conservative estimate of six percent (Tietenberg and Lewis, 2012 [p 63]; OMB Circular A-94, 1992 mandates 7 percent; Randall, 1987 [p 240]) for the opportunity cost rate for moving resources from the private to the public sector. Consistent with Barro (1990), the model assumes that the opportunity cost rate applies to small private-to-public transfers of resources. When a surplus (Revenue $>$ [Spending + BSF Deposit]) triggers a reduction in a state's Marginal Tax Rate, the model employs the conservative estimate in Poulson and Kaplan (2008) that a one percentage drop in a state's marginal tax rate increases that state's rate of economic growth 0.251 percent.

The state general fund revenue data, excluding Federal funds, come from the National Association of State Budget Officers (NASBO.org). Those data start in Fiscal Year 1998. Data gaps forced exclusion of Alaska and New Mexico. That eliminated the need to assess whether Alaska should be excluded, which is common, because of its unique revenue mix. Population data are from the Census Bureau. Personal income data are from the Bureau of Economic Analysis. The simulation analysis time period was 1998 to 2014 (economic growth years), which means the results are not biased by the choice of starting and ending years. After computing population plus inflation rates, and allowing for data availability lags, ${ }^{4}$ the model calculates each state's revised General Fund spending for 1999 onward as follows:

$$
\begin{aligned}
& \text { RSPEND }_{\mathrm{t}}=\left(\mathrm{RSPEND}_{\mathrm{t}-1} \mathrm{x}(1+\mathrm{TEL} \mathrm{t})\right) \\
& \text { When: } \text { RSPEND }_{\mathrm{t}}<\mathrm{RREV}_{\mathrm{t}} \\
& \text { or } \text { RSPEND }_{t}<\text { RREV }_{t}+\text { BSF }_{t} \\
& \text { Otherwise: } \text { RSPEND }_{t}=\mathrm{RREV}_{\mathrm{t}}+\mathrm{BSF}_{\mathrm{t}}
\end{aligned}
$$

\footnotetext{
${ }^{4}$ Fiscal year $\mathrm{N}$ budget-making must rely on the calendar year N-2 population estimate, and the May, N-1 CPI.
} 
With: RSPEND $_{\mathrm{t}}=$ revised General Fund (GF) spending in fiscal year $\mathrm{t}$

$\mathrm{TEL}_{\mathrm{t}}=$ the spending growth rate cap for fiscal year $\mathrm{t}$ as a decimal

$\mathrm{BSF}_{\mathrm{t}}=$ fiscal year $\mathrm{t}$ budget stabilization fund account balance

$\mathrm{RREV}_{\mathrm{t}}=$ year $\mathrm{t}$ General Fund revenue revised via dynamic scoring

A cap 'shortfall' (SHORTFALLt)occurs when: RSPEND $<$ (RSPENDt-1 x $(1+$ TELt)).

Shortfalls occur only after depletion of the BSF. The shortfall rate for year $t$ is:

SHFALLRATE $_{\mathrm{t}}=$ SHORTFALL $_{\mathrm{t}} / \mathrm{RREV}_{\mathrm{t}}$

Shortfalls reduce the RSPEND base for subsequent years creating the so-called ratchet-down effect (Poulson, 2009; Kioko, 2011). The year $t$ ratchet-down effect is: 1 - $\left(\right.$ RSPEND $_{t} /$ RSPENDMAX $\left._{t}\right)$. RSPENDMAX ${ }_{t}$ is the spending level in year $t$ if there had been no shortfalls prior to year $t$, or in year $t$. BSF outlays eliminate, reduce, or delay the ratchet-down effects of recessions.

Afirst Year ( $\mathrm{t}=0=1998$ ) BSF account balance results by applying the TEL cap to five previous years of spending data, ${ }^{5}$ and allocating the net difference between actual and simulated spending to $\mathrm{BSF}_{0}$. When cap level spending tops revenue $\left\{\left(\mathrm{RSPEND}_{\mathrm{t}-1} \mathrm{X}\left(1+\mathrm{TEL} \mathrm{L}_{\mathrm{t}}\right)\right)>\mathrm{RREV}_{\mathrm{t}}\right\}$, we debited the BSF as follows:

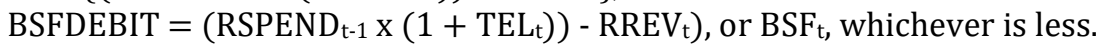

When cap level expenditure is less than revenue $\left\{\left(\operatorname{RSPEND}_{\mathrm{t}-1} \mathrm{x}\left(1+\mathrm{TEL}_{\mathrm{t}}\right)\right)<\operatorname{RREV}_{\mathrm{t}}\right\}$, we deposited funds into the BSF as follows:

BSFDEPOSIT $=\left(R^{2} V_{t}-R P S E N D_{t}\right)$ or $\left(\left(R S P E N D_{t} \times 0.1\right)-B F_{t-1}\right)$, whichever is less.

When $R R E V_{t}>R$ SPEND $_{t}$, surplus revenue may also be available for taxpayer rebates, and for deposit into other state accounts, such as for emergency preparedness and capital investment.

$$
\mathrm{SURP}_{\mathrm{t}}=\left(\mathrm{RREV}_{\mathrm{t}}-\mathrm{RSPEND}_{\mathrm{t}}\right)-\left(\mathrm{BSF}_{\mathrm{t}}-\mathrm{BSF}_{\mathrm{t}-1}\right)
$$

Surpluses trigger proportional marginal tax rate reductions. So, a surplus that is ten percent of revised revenue, together with a parameter that mandates cutting taxes by half of the surpluses share of revised revenue (NCYC $=$ 0.5), means a five percent MTR cut. If the TEL growth rule is a target rather than a limit, shortfalls, as defined above, trigger MTR increases. That yields personal income and tax revenue adjustments via dynamic scoring. When SURP $\mathrm{t}_{-1}>0$, the model increases economic growth $\left(\mathrm{GROWTH}_{\mathrm{t}}=\right.$ the increase in growth) beyond the level that actually occurred:

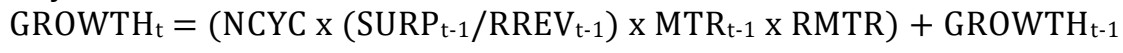

Where: $\mathrm{NCYC}=0.2$ in our simulations. Individual states would set NCYC at the perceived non-cyclical share of the surplus or shortfall.

$\mathrm{MTR}_{\mathrm{t}}=$ average MTR $\mathrm{from}_{\mathrm{t}}$ Skidmore et al (2011) adjusted for MTR changes. RMTR $=$ growth rate $\Delta$ per pct point drop in MTR (Poulson and Kaplan 2008).

To limit the scope of the analysis, we examined the TEL growth rules as limits, not targets. So, in our simulations, the extra GROWTH $\mathrm{t}_{\mathrm{t}}=\mathrm{GROWTH}_{\mathrm{t}-1}$ in zero surplus or shortfall years. That provides a basis for a revised personal income (RPI) estimate:

$$
\mathrm{RPI}_{\mathrm{t}}=\left(\left(\mathrm{RPI}_{\mathrm{t}-1} \mathrm{x}\left(1+\left(\left(\mathrm{API}_{\mathrm{t}}-\mathrm{API}_{\mathrm{t}-1}\right) / \mathrm{API}_{\mathrm{t}-1}\right)\right) \mathrm{x}\left(1+\mathrm{GROWTH}_{\mathrm{t}}\right)\right)+\left(\mathrm{OCR} \times \mathrm{SURP}_{\mathrm{t}}\right)\right.
$$

Where: $\mathrm{OCR}=$ opportunity cost rate (0.06); $\mathrm{API}_{\mathrm{t}}=$ actual personal income in fiscal year $\mathrm{t}$.

MTR change (lower tax rates) directly lowers tax revenue (STATIC), and then the personal income change that results from the MTR changes impacts tax revenue collection (DYNAMIC).

$$
\text { RREV }_{\mathrm{t}}=\text { STATIC }_{\mathrm{t}}+\text { DYNAMIC }_{\mathrm{t}}
$$

When $\mathrm{SURP}_{\mathrm{t}} \geq 0$ :

$$
\begin{gathered}
\text { DYNAMIC }_{\mathrm{t}}=\left(\mathrm{RPI}_{\mathrm{t}}-\mathrm{API}_{\mathrm{t}}\right) \mathrm{x}\left(\left(\mathrm{MTR}_{\mathrm{t}} / 100\right) \mathrm{x}\left(1-\left(\mathrm{NCYC}_{\mathrm{x}}\left(\mathrm{SURP}_{\mathrm{t}-1} / \mathrm{RREV}_{\mathrm{t}-1}\right)\right)\right)\right) \\
\text { STATIC }_{\mathrm{t}}=\left(\left(1+\left(\left(\mathrm{AREV}_{\mathrm{t}}-\mathrm{AREV}_{\mathrm{t}-1}\right) / \mathrm{AREV}_{\mathrm{t}-1)}\right) \mathrm{xRREV}_{\mathrm{t}-1}\right) \mathrm{x}\right. \\
\left(1-\left(\mathrm{NCYC}^{\mathrm{x}}\left(\mathrm{SURP}_{\mathrm{t}-1} / \mathrm{RREV}_{\mathrm{t}-1}\right)\right)\right)
\end{gathered}
$$

Where: $\operatorname{AREV}_{\mathrm{t}}=$ actual revenue for fiscal year $\mathrm{t}$.

\subsection{Empirical results}

We present results for two growth years (FY 2008 and FY 2014) and two recession years: FY 2003, the bottom of the 2001 Recession, and for FY 2010, the bottom of the Great Recession. More detailed simulation results are in an online technical appendix.

\footnotetext{
${ }^{5}$ NASBO's General Fund expenditure data series begins five years sooner than the revenue data series.
} 


\section{Constrained state spending growth}

The dynamic simulation analysis indicates that each of the TEL designs would have notably reduced state spending over the time period analyzed. Table 1 compares the ratio of simulated to actual spending. The 2008 and 2014 TEL impacts are not influenced by the effects of a recession.

\begin{tabular}{lrrrrr}
\hline \multicolumn{7}{c}{ Table 1: Ratio of simulated to actual spending } \\
\hline TEL Cap Basis & FY1999 & FY2003 & FY2008 & FY2010 & FY2014 \\
\hline Pop+Infl & $94.6 \%$ & $91.1 \%$ & $77.7 \%$ & $85.9 \%$ & $80.5 \%$ \\
(Pop+Infl)x1.2 & $95.5 \%$ & $93.2 \%$ & $82.0 \%$ & $88.7 \%$ & $84.1 \%$ \\
One-Yr $\Delta$ PI & $98.7 \%$ & $97.9 \%$ & $90.2 \%$ & $92.3 \%$ & $87.5 \%$ \\
Ten-YrAvg $\Delta$ PI & $98.2 \%$ & $98.1 \%$ & $89.4 \%$ & $93.6 \%$ & $90.0 \%$ \\
\hline
\end{tabular}

After fifteen years, the basic population growth plus inflation basis constrains average state spending 7.5 to ten percentage points more than TELs based on personal income growth; about twice as much growth reduction as the growth at long-run personal income growth rates. The (Pop+Infl)x1.2 TEL ends the 15-year period roughly splitting the difference between the basic population growth plus inflation basis and the Personal Income TELs; without the volatility of the Personal Income TELs. ${ }^{6}$

The ratio of spending to personal income (Table 2) tells a similar story, again, as early as the first year, 1999; a year of rapid spending growth in most states. The TEL linked to population growth and inflation yields the sharpest drop (to $4.08 \%$ ) in the ratio of simulated spending to dynamic scoring-revised personal income. Spending is half a percentage point larger at $4.57 \%$ with the least stringent Personal Income TEL.

\begin{tabular}{lrrrrr}
\hline \multicolumn{6}{c}{ Table 2: Ratio of simulated spending to personal income } \\
\hline TEL Cap Basis & FY1999 & FY2003 & FY2008 & FY2010 & FY2014 \\
\hline Pop+Infl & $5.28 \%$ & $4.89 \%$ & $4.29 \%$ & $4.39 \%$ & $4.08 \%$ \\
(Pop+Infl)x1.2 & $5.33 \%$ & $5.00 \%$ & $4.53 \%$ & $4.54 \%$ & $4.27 \%$ \\
One-Yr $\Delta$ PI & $5.50 \%$ & $5.27 \%$ & $4.99 \%$ & $4.74 \%$ & $4.46 \%$ \\
Ten-YrAvg $\Delta$ PI & $5.47 \%$ & $5.28 \%$ & $4.93 \%$ & $4.80 \%$ & $4.57 \%$ \\
\hline
\end{tabular}

\section{Ratchet down' effects}

The simulations set each year's cap amount as growth from the current year, so shortfalls lower future spending limits. Another study (Merrifield and Poulson, 2014a) explores the alternate approach wherein the TEL limit grows over time independent from actual revenue and spending. Table 3 indicates how much the size of government depends on ratchet-down effects of the different TELs. Years of economic growth and recovery, FY 2008 and FY 2014, are chosen to capture the cumulative average ratchet down effect. With the population plus inflation TELs, fewer states see ratchet-down effects, and where present, the ratchet-down effect is smaller. Part of the reason for the large differences between the population-plus-inflation and personal income TELs, and between the simulated 2008 and 2014spending with the personal income TELs and the no-shortfall level is that the personal income TELs are widely non-binding in the long-run; binding in some states in high economic growth years, but not over multiple years.

Table 3: Average ratchet-down effects of those ratcheted down

\begin{tabular}{lrr} 
TEL Cap Basis & FY 2008 & FY 2014 \\
\hline POP+INFL & $10.1 \% / 17$ & $14.2 \% / 30$ \\
(POP+ INFL)x1.2 & $12.2 \% / 19$ & $18.3 \% / 34$ \\
One-YR PI & $13.6 \% / 33$ & $23.9 \% / 46$ \\
Ten-YR PI & $14.1 \% / 33$ & $25.1 \% / 47$ \\
\hline
\end{tabular}

The personal income TEL ratchet-down effects are larger than the gap between simulated and actual spending. That is, most states would have spent more in 2008 and 2014 than they actually spent those years had they grown their General Fund spending every year by the personal income TEL cap rate. But with ratchet-down effects, even limiting spending growth over actual previous spending to personal income growth amounts to a long-run strategy to shrink the relative size of moststate governments. That could be a legitimate strategy; to have periodic lean years to pressure legislators to assess spending priorities and eliminate marginal programs. For those who favor that, note from Table 7 that fifteen states (48 minus 33) were able to keep spending growing every year

${ }^{6}$ Other findings; beyond the scope of this article. 
through 2008 by either personal income growth measure. It took the severity of the Great Recession to knock all but one or two of them off that path. With population plus inflation as the TEL cap basis, it does not take ratchetdown effects to shrink state governments, though for many states, the ratchet-down effects dominate the other grounds for reductions in spending growth.

\section{Sensitivity analysis}

The Monte Carlo process for every combination of our parameter test values yielded 768 observations. The parameter test values included the preferred values described earlier, and at least one plausible alternative. For example, the BSF account limit parameter had three test values; $10 \%$ (preferred value), $15 \%$, and $25 \%$ of General Fund spending. An ordinary least squares regression of the 768 observations generated by the Monte Carlo process yielded estimates of the average marginal effect of each parameter.

Because the personal income TEL basis is often not a limit, and possibly an un-attractive basis for a part-time limit, we focused our Monte Carlo-based, general sensitivity tests on the Population plus Inflation TEL basis. The OLS regressions yielded the $99 \%$ significant coefficients in Table 4. Noteworthy from the regressions is that the rate at which surplus revenue goes to the BSF (when BSFCRED $\geq 50 \%$, the minimum test value) does not significantly affect any outcome. The average marginal effect of a change from Pop+Infl to (Pop+Infl)x1.2 is $1 / 5$ th of the first row's coefficients. Upping MULT from 1.0 to 1.2 (by $1 / 5^{\text {th }}$ ) raises the ratio of average 2014 general fund spending to personal income by nearly $1 / 4$ percentage point $\left(1 / 5^{\text {th }}\right.$ of 0.0114$)$.

\begin{tabular}{lcrr}
\hline \multicolumn{4}{c}{ Table 4: OLS regression of Monte Carlo observations } \\
\hline MULT & 2014 GF/PI & GF Spend Sim/Act Ratio & Average Ratchet Down by 2014 \\
BSFCRED & 0.0114 & 0.2115 & 0.1762 \\
BSFDEB & & & 0.0146 \\
BSFCAP & & & -0.0319 \\
OCR & 0.0064 & 0.1249 & 0.0227 \\
NCYC & & & -1.1851 \\
RMTR & -0.0080 & -0.1563 & 0.89 \\
R-Squared & 0.1499 & 3.5787 & 0.926 \\
\hline
\end{tabular}

The average effect of changing MULT from 1.0 to 1.2 is a 3.5\% increase in the degree of ratchet down, including eight more states (not shown) with ratchet down by 2014. The BSFCAP coefficients indicate that a five percentage point increase in the allowed size of the budget stabilization fund (for example, from ten to fifteen percent of General Fund spending) would increase simulated spending's share of personal income by 0.032 percent (five times 0.0064 ), raising the ratio of simulated to actual spending by 0.625 percent, and decreasing ratchet down by 0.16 percent. A ten percentage point increase in the tax cut response to surplus revenue (NCYC $=0.2 \mathrm{vs}$. 0.1 ) cuts the average size of the state government's share of personal income by 0.08 percent, and it cuts the 2014 ratio of simulated to actual spending by 1.6 percent. NCYC $=0.2$ vs 0.1 increases the average degree of ratchet down by 2014 by 0.23 percent. The large RMTR coefficients are deceptive. The RMTR changes - changes in dynamic scoring effects - are statistically significant explanatory variables, but the Monte Carlo tests only vary RMTR by about $1 / 10$ of one percentage point. So, a change in RMTR from 0.00251 to 0.00374 would increase 2014 state spending's (more revenue to spend) share of personal income by 0.018 percent, increase the 2014 ratio of simulated to actual spending by 0.44 percent, and decrease the average ratchet-down effect by 0.15 percent.

\subsection{Conclusion}

The fiscal stress experienced by the states in recent recessions, and slow growth alongside rapid state government expansion in some states renewed interest in TELs; TELs with lower caps and less likely to be circumvented or gutted because of excessive stringency. Existing TELs have mostly done little to constrain state spending. A 48state, 1998-2014 dynamic scoring simulation model adds to that literature by exploring differences in the impact of two population growth plus inflation TELs and two personal income growth TELs; designs that are representative of the TEL measure revisions introduced in most states. Each of those four TEL designs significantly reduced state spending relative to actual state spending. Our model measured the average differences between two population plus inflation TELs and two personal income TELs. Individual states can use the model to assess how the TEL alternatives would impact them.

A controversial issue in the TEL literature is the potential for cumulative 'ratchet down' effects over time. Our model identified likely significant 'ratchet down' effects of differences in TEL design. Periodic ratchet down effects can yield some desirable effects alongside the fiscal stress they create, and likely pressure to weaken the TEL. 
The population growth plus inflation x1.2 TEL could be a good compromise in the tradeoff between tight limits with greater stability and faster economic growth, and accommodation of some of the spending pressures - some beyond the control of state-level policymakers - that could otherwise yield constitutional amendments that gut a TEL; that have an extensive history of doing so. For spending hawks, a slightly larger rate of state spending growth may be a price worth paying for increased political sustainability. Another likely political sustainability factor is a budget stabilization fund (BSF) with clear, stringent deposit/withdrawal rules. The tradeoff here is a somewhat higher rate of spending growth for fewer political support-eroding ratchet-down effects. Measurement of the likely BSF-generated improvement in budget stability - less fiscal stress - is another political durability factor that is beyond the scope of this article.

\section{References}

Abrams, B., and A.Dougan."The Effects of Constitutional Restraints on Government Spending." Public Choice, 49(2), 1986,101-16. http://dx.doi.org/10.1007/BF00181033

Agenor, P. and D. Yilmaz."The Tyranny of Rules: Fiscal Discipline, Productive Spending, and Growth in a Perfect Foresight Model." Journal of Economic Policy Reform, 14(1), 2011, 69-99. http://dx.doi.org/10.1080/17487870.2010.503086

Amiel, L.,S. Deller, and J. Stallman. "Economic Growth and Tax Expenditure Limitations." Review of Regional Studies, 42, 2012, 185-206.

Bails, D. "The Effectiveness of Tax and Expenditure Limits: a Re-Evaluation." American Journal of Economics and Sociology, 49(2), 1990, 223-238. http://dx.doi.org/10.1111/j.1536-7150.1990.tb02274.x

Bails, D., and M. Tieslau."The Impact of Fiscal Constitutions on State and Local Expenditures." Cato Journal, 20(2), 2000,255-277.

Bania, N. and Stone, J.A. "Ranking State Fiscal Structures: Using Theory and Evidence," Journal of Policy Analysis and Management, 27(4), 2008, 751-770

Barro, R." Government Spending in a Simple Model of Endogenous Growth." Journal of Political Economy, 98(1), 1990, 103-117. http://dx.doi.org/10.1086/261726

Bennet, J.T., and T.DiLorenzo.1982. "Off-Budget Activities of Local Government." Public Choice, 39(3), 1982, 333342.

Bergh, A. and M. Henrekson. "Government Size and Growth: A Survey and Interpretation of the Evidence." Journal of Economic Surveys,25, 2011, 872-97. http://dx.doi.org/10.1111/j.1467-6419.2011.00697.x

Bird, G., and A. Mandilaras. "Fiscal Imbalances and Output Cries in Europe: Will the Fiscal Compact Help or Hinder?" Journal of Economic Policy Reform, 16(1), 2013, 1-16. http://dx.doi.org/10.1080/17487870.2013.765081

Chapman, S. "A Hole They Dug for Themselves." Reasonline (July 30, 2009), http:// www.reason.com/news/show/135123.html

Crain, M. Volatile States: Institutions, Policy, and the Performance of American State Economies. Ann Arbor, MI: University of Michigan Press, 2003. http://dx.doi.org/10.3998/mpub.16580

Dahlby, B. "Progressive Taxation and the Social Marginal Cost of Public Funds." Journal of Public Economics, 67(1), 1998, 105-122. http://dx.doi.org/10.1016/S0047-2727(97)00049-2

Deller, S., J. Stallman, and L. Amiel."The Impact of State and Local Tax and Expenditure Limits on State Economic Growth." Growth and Change,43, 2012, 56-84. http://dx.doi.org/10.1111/j.1468-2257.2011.00577.x

Douglas, J.W., and R.K. Gaddie."State Rainy Day Funds and Fiscal Crises: Rainy Day Funds and the 1990-1991 Recession Revisited." Public Budgeting \& Finance, 22(1), 2002, 19-30. http://dx.doi.org/10.1111/15405850.00063

Elder, H. "Exploring the Tax Revolt: an Analysis of the Effectiveness of State Tax and Expenditure Limitation Laws. Public Finance Quarterly, 20(1), 1992, 47-63. http://dx.doi.org/10.1177/109114219202000103

Eliason, P., and Lutz, B. 2015. Can fiscal rules constrain the size of government? An analysis of the crown jewel of tax and expenditure limitations. Mimeo.

Fatas, A., and I. Mihov. "The Macroeconomic Effect of Fiscal Rules in the U.S. States." Journal of Public Economics, 90, 2006, 101-117. http://dx.doi.org/10.1016/j.jpubeco.2005.02.005

Gold, S.D. Preparing for the Next Recession: Rainy Day Funds and Other Tools for the States. Legislative Finance Paper No. 41, National Conference of State Legislatures, 1983.

Holcombe, R. and R. Sobel. Growth and Variability in State Tax Revenue. London: Greenwood Press, 1997.

Howard, M. Tax and expenditure limitations: there is no story. Public Budgeting and Finance 9, 1989, 83-90. http://dx.doi.org/10.1111/1540-5850.00820

Joyce, P., and Mullins, D. "The changing fiscal structure of the state and local public sector: the impact of tax and expenditure limits. Public Administration Review 51, 1991, 240-53. http://dx.doi.org/10.2307/976948

Kalita, M. "Governors Try to Convince Voters that Budget Woes are Theirs, Too." Wall Street Journal, October19, 2009, A2. 
Kioko, S., and Martell, C. "Impact of state level tax and expenditure limits (TELs) on government revenues and aid to local governments." Public Finance Review 40(6), 2012, 736-766. http://dx.doi.org/10.1177/1091142112438460

Kioko, S.N. "Structure of State-Level Tax and Expenditure Limits." Public Budgeting \& Finance,31(2), 2011, 43-79. http://dx.doi.org/10.1111/j.1540-5850.2011.00979.x

Kousser, T., M. McCubbins, and E. Moule. "For Whom the TEL Tolls: Can State Tax and Expenditure Limits Effectively Reduce Spending?" State Politics and Policy Quarterly, 8, 2008, 331-361. http://dx.doi.org/10.1177/153244000800800401

Knight, B., and A. Levinson, A. "Rainy Day Funds and State Government Savings." National Tax Journal, 52(3), 1999, 459-72.

Krol, R. "The Role of Fiscal and Political Institutions in Limiting the Size of State Government." Cato Journal, 27(3), 2007, 431-445.

Ladner, M., and B. Schlomach. Government Growth or Poverty Reduction? Lessons from the States. Austin, TX: Texas Public Policy Foundation, 2007, RR 01-2007 Available at www.texaspolicy.com/pdf/ 2007-01-RR01poverty-ladner-bs.pdf

Lav, I. J. TABOR Has Hampered Economic Growth and Reduced the Quality of Life in Colorado. Washington, DC: Center on Budget and Policy Priorities (October, 2009).

Lav, I. J., and E. Williams. Tax and Spending Limits. Washington, DC: Center on Budget and Policy Priorities (March, 2010).

Lyons, K., and N. Johnson. Education Investment, Not TABOR, Fueled Colorado's Economic Growth in the 1990s. Washington, DC: Center on Budget and Policy Priorities (March, 2006).

Makin, A.J. "Expansionary Versus Contractionary Government Spending." Contemporary Economic Policy, 33(1), 2015, 56-65. http://dx.doi.org/10.1111/coep.12051

McBride, W. What Is the Evidence on Taxes and Growth? Washington: Tax Foundation, Special Report No. 207, 2012. Available at http://taxfoundation.org/article/what-evidence-taxes-and-growth.

McGuire, T., and K. S. Reuben. The Colorado Revenue Limit: The Economic Effects of TABOR. Washington, DC: Economic Policy Institute, (March, 2006).

Merrifield, J. "Factors That Influence the Level of Underground Government." Public Finance Quarterly,22(4), 1994, 462-82. http://dx.doi.org/10.1177/109114219402200404

Merrifield, J. and D. Monson. "Simulation of a Constitutional Spending Limit for a Conservative State: with Dynamic Adjustment and Sensitivity Analysis." Public Budgeting \& Finance, 31(3), 2011, 1-25. http://dx.doi.org/10.1111/j.1540-5850.2011.00984.x

Merrifield, J. "State Government Expenditure Determinants and Tax Revenue Determinants Revisited." Public Choice, 102(1-2), 2000, 25-50. http://dx.doi.org/10.1023/A:1005036918713

Merrifield J., and B. Poulson. "Ratchet-Down Effects of Spending Caps: A Dynamic Scoring Simulation Analysis." Denver: Western Economic Association International, 2014a.

Merrifield J. and B. Poulson."State Fiscal Policies for Budget Stabilization and Economic Growth: a Dynamic Scoring Analysis." Cato Journal, 34(1), 2014b, 47-81.

Merrifield J., and B. Poulson. Can the Debt be Stopped?: Rules Based Policy Options for Addressing the Federal Fiscal Crisis. (forthcoming) Lexington, MA: Lexington Books, 2016.

Mitchell, M. TEL It Like It Is: Do State Tax and Expenditure Limits Actually Limit Spending? George Mason University: Mercatus Center, Working Paper No. 10-71, 2010.

Mitchell, M., and N. Tuszynski. Institutions and State Spending: An Overview. George Mason University: Mercatus Center, Working Paper No. 11-39 (October, 2011).

Mullins, D., and Joyce, P. "Tax and expenditure limitations and state and local fiscal structure: an empirical assessment." Public Budgeting and Finance 16, 1996, 75-101. http://dx.doi.org/10.1111/1540-5850.01061

Mullins, D., and B. Wallin. "Tax and Expenditure Limitations: Introduction and Overview." Public Budgeting \& Finance,24(4), 2004, 2-15. http://dx.doi.org/10.1111/j.0275-1100.2004.00344.x

New, M. Limiting Government through Direct Democracy: The Case of Tax and Expenditure Limitations. Washington, DC: Cato Institute Policy Analysis No. 420, 2001.

Office of Management and Budget. Circular A-94, 1992.

Padquit, K. (2011) State Business Tax Climate Index, 8th ed. Washington, DC: Tax Foundation.

Peterson, W. "Over-Investment in Public Sector Capital." Cato Journal,14(1), 1994, 2011, 1-6.

Poterba, J., and Reuben, K. 1999. Fiscal rules and state borrowing costs: evidence from California and other states. San Francisco, CA: Public Policy Institute of California.

Poterba, J. "Budget Institutions and Fiscal Policy in the States." American Economic Review, 86(2), $1996,395-400$.

Poterba, J. "State Responses to Fiscal Crises: the Effects of Budgetary Institutions and Politics. The Journal of Political Economy, 102(4), 1994, 799-821. http://dx.doi.org/10.1086/261955

Poulson, B. Tax and Spending Limits: Theory, Analysis, and Policy. Denver: Independence Institute Issue Paper IP2-2004, 2004. 
Poulson, B., and J. Kaplan. (1994) "A Rentseeking Model of TELs." Public Choice, 79(1-2), 117-134 http://dx.doi.org/10.1007/BF01047922

Poulson, B., and J. Kaplan. (2008) "State Income Taxes and Economic Growth." Cato Journal, 28(1), 53-71.

Primo, D.M. "Stop Us Before We Spend Again: Institutional Constraints On Government Spending." Economics \& Politics, 18(3), 2006, 269-312. http://dx.doi.org/10.1111/j.1468-0343.2006.00171.x

Randall, A. Resource Economics (2nd Ed). NY: John Wiley \& Son, 1987.

Rueben, K. and C. Rosenberg. (2009) "State and Local Tax Policy: What Are Rainy Day Funds and How Do They Work," in: The Tax Policy Briefing Book. Washington, DC: Tax Policy Center.

Reed, R.W.,C.L. Rogers, and M. Skidmore. "On Estimating Marginal Tax Rates for U.S. States." National Tax Journal,64(1), 2011, 59-84. http://dx.doi.org/10.17310/ntj.2011.1.03

Reuben, K., and C. Rosenberg. "State and Local Tax Policy: What Are Rainy Day Funds and How Do They Work?" in: Tax Policy Briefing Book, Washington, DC: Tax Policy Center (August 2009).

Schunk, D., and D. Woodward. "Spending Stabilization Rules: a Solution to Recurring State Budget Crises." Public Budgeting \& Finance, 25(4), 2005, 105-124. http://dx.doi.org/10.1111/j.1540-5850.2005.00376.x

Shadbegian, R. "Do Tax and Expenditure Limitations Affect the Size and Growth of State Government?" Contemporary Economic Policy, 14(1), 1996, 22-35. http://dx.doi.org/10.1111/j.14657287.1996.tb00600.x

Sobel, R.S. "The Political Costs of Tax Increases and Expenditure Reductions: Evidence from State Legislative Turnover." Public Choice, 96(1-2), 1998, 61-79. http://dx.doi.org/10.1023/A:1004953215739

Spencer, R.W., and W.P. Yohe. "The Crowding Out of Private Expenditures by Fiscal Policy Actions." Federal Reserve Bank of St. Louis Review (October, 1970), 12-24.

Stallman J. "State Tax and Expenditure Limitations and Economic Performance." Public Budgeting \& Finance, 31(4), 2011, 109-35. http://dx.doi.org/10.1111/j.1540-5850.2011.00995.x

Stallman J., and S. Deller. "Impact of State and Local Tax and Expenditure Limits on Economic Growth." Applied Economic Letters,17, 2010, 645-48. http://dx.doi.org/10.1080/13504850802297954

Stansel, D. Taming Leviathan: Are Tax and Spending Limits the Answer? Washington, DC: Cato Institute Policy Analysis No. 213, 1994.

Stansel, D., and D. Mitchell. "State Fiscal Crises: are Rapid Spending Increases to Blame?" Cato Journal, 28(3), 2008, 435-448.

Taylor, J.B. "Why Permanent Tax Cuts Are the Best Stimulus." Wall Street Journal, November 25, 2008.

Tietenberg, T., and A. Lewis. Environmental and Natural Resource Economics (9th Ed.). Boston, MA: Pearson, 2012.

Vock, D., P. Prah,S. Fehr, M. Stephen, M. Maynard, J. Gramlich, and K. Leonard. Beyond California: States in Fiscal Peril. Washington, DC: Pew Center on the States, 2009.

Wagner, G.A. "Are State Budget Stabilization Funds Only the Illusion of Savings: Evidence From Stationary Panel Data." Quarterly Review of Economic and Finance,43(2), 2003, 2213-38. http://dx.doi.org/10.1016/S10629769(01)00132-6

Wagner, G.A. "The Bond Market and Fiscal Institutions: Have Budget Stabilization Funds Reduced State Borrowing Costs?" National Tax Review, 57(4), 2004, 75-804. http://dx.doi.org/10.17310/ntj.2004.4.01

Wagner, G., and E. Elder. "The Role of Budget Stabilization Funds in Smoothing Government Expenditures over the Business Cycle." Public Finance Review, 33(4), 2005, 439-465. http://dx.doi.org/10.1177/1091142105276442

Wagner, G., and E. Elder. "Revenue Cycles and the Distribution of Shortfalls in U.S. States: Implications for an Optimal Rainy Day Fund." National Tax Journal, 60(4), 2007, 727-742. http://dx.doi.org/10.17310/ntj.2007.4.03

Wagner, G., and R. Sobel. "State Budget Stabilization Fund Adoption: Preparing for the Next Recession or Circumventing Fiscal Constraints?" Public Choice, 126(1-2), 2006, 177-199. http://dx.doi.org/10.1007/s11127-006-7752-x

Waisanen, B. State Tax and Expenditure Limits-2010. Washington, DC: National Conference of State Legislatures, 2010.

Young A., and R. Sobel."Recovery and Reinvestment Act Spending at the State Level: Keynesian Stimulus or Distributive Politics." Public Choice, 155(3-4), 2013, 449-468. http://dx.doi.org/10.1007/s11127-0119876-x

Zycher B. (May, 2013) State and Local Spending: Do Tax and Expenditure Limits Work? Washington, DC: American Enterprise Institute.

Appendix: http://faculty.business.utsa.edu/jmerrifi/TEL-Basic.pdf 